\title{
Analysis of seroprevalence against Coxiella burnetii in a sample of farm workers in Western Sicily
}

\author{
MG Verso', G Vesco², S Villari², P Galluzzo², V Gargano², D Matranga³, P De Marchis', D Picciotto' \\ ${ }^{1}$ Department of Sciences for Health Promotion and Mother-Child Care 'G. D'Alessandro', Occupational Health Section, \\ University of Palermo, Italy \\ ${ }^{2}$ Istituto Zooprofilattico Sperimentale della Sicilia, Palermo, Italy \\ ${ }^{3}$ Department of Sciences for Health Promotion and Mother-Child Care 'G. D'Alessandro', Hygiene Section, University of \\ Palermo, Italy \\ Verso $\mathrm{MG}^{1}$, Vesco $\mathrm{G}^{2}$, Villari $\mathrm{S}^{2}$, Galluzzo $\mathrm{P}^{2}$, Gargano $\mathrm{V}^{2}$, Matranga $\mathrm{D}^{3}$, De Marchis $\mathrm{P}^{1}$, Picciotto $\mathrm{D}$. Analysis of seroprevalence against Coxiella \\ burnetii in a sample of farm workers in Western Sicily. Ann Agric Environ Med. 2016; 23(1): 71-74. doi: 10.5604/12321966.1196855
}

\section{Abstract}

Introduction and objective. Little is known about the development of chronic Q fever caused by Coxiella burnetii in occupational risk groups and in the general population in Italy, as well as in many countries in the world. The aim of this study was to highlight the presence of the infection in a sample of workers operating outdoors (but not directly in contact with animals), in three provinces of western Sicily, in order to detect the human seroprevalence and compare the obtained data with those found in animals raised in the same territory.

Materials and methods. The study included 126 generic seasonal agricultural workers (labourers), 84 male and 42 female; none of whom were aware of any previous contact with Coxiella burnetii. Their immunologic status against Coxiella burnetii was tested through research and titration of both phases I and II specific antibodies (IgG) with an indirect immunofluorescence assay, using anti-antibodies labeled with fluorescein isothiocyanate. All data were statistically analyzed, comparing all positive results from the three provinces through variance analysis, and then comparing human results with those obtained from animals raised in the considered areas, specifically, 1,511 cows, 46 of which were found positive (3.04\%), and 3,391 sheep, 548 of which were found positive (16.16\%).

Results. Anti-Coxiella antibodies were found in nine of 42 females sampled $(21.4 \% ; 95 \% \mathrm{Cl}=[9.0-33.8])$ and 21 of 84 males sampled $(25.0 \% ; 95 \% \mathrm{Cl}=[15.7-34.3]) .60 \%$ (18 of 30; $95 \% \mathrm{Cl}=[42.5-77.5]$ ) of seropositive samples were positive either for Phase I antigen or for both Phase I and II antigens, representing cases of chronic infection. Applying Spearman's rank correlation, the percentage of seropositive humans was significantly correlated with that observed for sheep $(r=1.00 ; p<0.001)$, but not for cows $(r=-0.5 ; p=0.667)$.

Conclusions. The results obtained, although based on a small sample, suggest that the disease is present in the territory of Western Sicily, both in animals and in humans. A closer collaboration between doctors and veterinarians is therefore necessary to fight against the spread of the infection.

\section{Key words}

Q fever, environmental exposure, Coxiella burnetii

\section{INTRODUCTION}

Q fever is a zoonosis caused by Coxiella burnetii, an obligate intracellular pathogen infecting different animals, especially cows, sheep and goats, usually through ticks that act as carriers. These animals may constitute a reservoir for infection, as well as birds and arthropods. Human infection occurs primarily through inhalation of dust coming from infected stables, slaughterhouses, or animal derivatives (skins, wool), or by contact with urine, milk, excrements and other excreta of infected animals, wherein the disease is manifested with pneumonia, but also with abortions and infertility [1]. The disease, present throughout the world, is an occupational hazard for those who work in rural settings and in contact with animals, especially the operators of the livestock industry (veterinarians, tanners, and wool carders). This motivated some countries to undertake vaccination

Address for correspondence: Maria Gabriella Verso, Department of Sciences for Health Promotion and Mother-Child Care 'G. D'Alessandro', Occupational Health Section, University of Palermo, via del Vespro 143, 90127 Palermo, Italy

E-mail: mariagabriella.verso@unipa.it

Received: 13 April 2015; accepted: 21 July 2015 programmes for workers at risk of contracting the disease [2-19].

In humans, $\mathrm{Q}$ fever can cause symptoms similar to influenza, with fever and headache, diarrhea and vomiting; in severe cases, it can result in pneumonia. The incubation period varies from one to four weeks: the onset is sudden, with fever that can reach $40^{\circ} \mathrm{C}$, severe headache, chills, malaise, myalgia, and often chest pain. Chronic Q fever, characterized by an infection lasting more than six months, is uncommon, but much more serious. In addition to the pulmonary localization, in the chronic form, hepatitis and endocarditis may be experienced. Chronic forms affect almost exclusively individuals with predisposing conditions, such as subjects with valvular heart diseases, patients with vascular problems or immunodeficiency. The symptoms can also occur after months or years after the infection. Endocarditis and vascular infections from chronic $Q$ fever usually lead to death if not treated with appropriate antibiotics for at least 18 months, and require up to a lifetime of treatment. Diagnosis is based on clinical signs and a specific serodiagnosis, using methods such as indirect immunofluorescence (IFA), ELISA and complement fixation test (CFT) for the detection of 
phase I and II antibodies, specific against the two different antigenic phases of C. burnetii. Both phases are important for the serodiagnosis. In particular, the reactivity to phase II corresponds to the acute form of the disease, while positivity to phase I or both corresponds to the chronic form. IgM antibodies against phase II antigens can be sought two weeks after infection, and persist for about two months; Ig $\mathrm{G}$ antibodies against phase I antigens appear after about 12 weeks and persist in serum for years. Molecular diagnosis through the research of bacterial DNA is increasingly being used [20]. During the acute phase, it is possible to isolate $C$. burnetii from blood, lungs, spleen and liver of the affected individual. Therapy is based on tetracycline.

$Q$ fever was recognized for the first time as a zoonosis in 1935, when some workers of an Australian slaughterhouse contracted the disease. Q fever, very often asymptomatic, it is not always diagnosed, therefore the available data often underestimate the size of the phenomenon in a geographic area. At the present time, in Italy and other European countries, the exact number of humans and ruminants with $\mathrm{Q}$ fever infection is unknown [21], often because people with antibodies against Coxiella burnetii show no obvious signs of the disease.

\section{OBJECTIVE}

To highlight the spreading of infection with Coxiella burnetii in a sample of workers operating outdoors (but not directly in contact with animals), in three provinces of western Sicily, in order to detect the human seroprevalence and compare the obtained data with those found in animals raised in the same territory.

\section{MATERIALS AND METHOD}

The study included 126 generic seasonal agricultural workers (labourers), 84 male and 42 female, with mean age 47.8 ( \pm DS 10.3 ) and average length of work 18.5 years ( \pm DS 10.3$)$. These individuals lived and worked in three provinces of Western Sicily: 62 (49.2\%) in Palermo, 20 (15.9\%) in Trapani, 44 (34.9\%) in Agrigento. None of them, as part of their work, was in direct contact with animals. For each worker, a professional conducted an objective examination, which included a preliminarily medical record (anamnesis) collecting information such as professional risks, relatives' diseases, and personal pathologies, remote and proximate. A venipuncture was performed for the evaluation of routine tests, such as: blood count, transaminases AST and ALT, GGT, BUN, creatinine, glucose, in order to establish possible changes in the baselines of the main function indexes for: blood-bone marrow, liver and kidneys. Thus, the immunologic status against Coxiella burnetii was established through research and titration of phase I and II specific antibodies (IgG).
The performed test was an indirect immunofluorescence allowing the antibodies possibly present in the sample to bind to the antigens fixed on the slide, and to be detected using anti-antibodies labeled with fluorescein isothiocyanate. The apparatus used in the test is the fluorescence microscope Leica DMLB with FITC filter for reading the slides. The blood sera determining elementary bodies visible and fluorescent when diluted 1:16 were assessed as positive, and checked for discriminating between Phase I and Phase II antibodies. All data were statistically analyzed, comparing positive individuals in the various provinces through analysis of variance, and then comparing human results with those obtained from animals raised in the considered areas.

Statistical analysis. For the preliminary analysis, one-way ANOVA test was used to investigate the distribution of age and job seniority with respect to the farmers' provenance. At univariate analysis, the association between the occurrence of positive antibodies and demographical and professional variables was assessed using either the $\chi^{2}$ test or Fisher's exact test, as appropriate. The correlation between seropositivity in humans and either cows and sheep was calculated through the Spearman's rank correlation. For age and job seniority, the median was used as cut-off value and values not less/more than the median were categorized as $0 / 1$. A $p$ value $\leq 0.05$ was considered as statistically significant. To measure the association level, crude Odds Ratio (OR) and the $95 \%$ corresponding test-based Confidence Interval (CI) were calculated. Multivariate analysis was executed only in the case of at least two statistically significant variables in univariate analysis. Statistical analysis was performed by using Stata MP/11.2 software.

\section{RESULTS}

The characteristics of enrolled subjects, total number of farm workers, gender, average age and job seniority are all summarized in Table 1 . The composition of the sample was not significantly different among the three examined provinces with respect to gender $(\mathrm{p}=0.563)$, while it was significant by age $(\mathrm{p}=0.019)$ and seniority $(\mathrm{p}=0.001)$.

None of these subjects reported in anamnesis any suggestive events of possible contamination, such as working in stables, or being in direct contact with animals. Only one male worker in the province of Agrigento reported the occurrence of a tick bite in the past, but he was not infected with Coxiella burnetii, resulting negative to both phases.

None of the respondents had any febrile respiratory illness in place. In addition, no abnormal findings were detected in routine blood tests.

Anti-Coxiella antibodies were found in nine of 42 females sampled $(21.4 \% ; 95 \% \mathrm{CI}=[9.0-33.8])$ and 21 of 84 males sampled $(25.0 \% ; 95 \% \mathrm{CI}=[15.7-34.3])$. The distribution of

Table 1. Composition of the sample of 126 Sicilian farmers by gender, age and seniority

\begin{tabular}{|c|c|c|c|c|c|c|c|c|c|}
\hline \multirow{2}{*}{ Provinces } & \multirow{2}{*}{$\mathrm{N}^{\circ}$} & \multicolumn{2}{|r|}{ Males } & \multicolumn{2}{|r|}{ Females } & \multicolumn{2}{|c|}{ Age (mean $\pm D S)$} & \multicolumn{2}{|c|}{ Job seniority } \\
\hline & & $\mathrm{n}$ & $\mathrm{n}(\%)$ of positive & $n$ & $n(\%)$ of positive & Total samples & Positive only & Total samples & Positive only \\
\hline Overall & & 84 & $21(25.0)$ & 42 & $9(21.4)$ & $47.8 \pm 10.3$ & $46.2 \pm 2.4$ & $18.5 \pm 10.3$ & $15.5 \pm 12.4$ \\
\hline Palermo & 62 & 39 & $8(20.5)$ & 23 & $3(13.0)$ & $50.2 \pm 9.4$ & $51.6 \pm 10.7$ & $20.8 \pm 9.3$ & $21.6 \pm 12.5$ \\
\hline Trapani & 20 & 13 & $4(30.8)$ & 7 & $5(71.4)$ & $42.6 \pm 10.9$ & $45.5 \pm 11.1$ & $10.8 \pm 9.2$ & $11.2 \pm 10.3$ \\
\hline
\end{tabular}


positive females was significantly different by province $(\mathrm{p}=0.002)$, but not the distribution of positive males $(\mathrm{p}=0.782)$. The sample composition for positive workers was not significantly different among the three provinces with respect to age $(\mathrm{p}=0.130)$ and job seniority (ANOVA $\mathrm{p}=0.116)$ (Tab. 1).

The greatest percentage of workers with anti-Coxiella antibodies occurred in Trapani (45.0\%), significantly higher than the results observed in Agrigento (22.7\%) and Palermo $(17.7 \%)(\mathrm{p}=0.044)$. There was no significant difference in the prevalence of the infection, neither by gender $(\mathrm{p}=0.657)$ nor by age $(\mathrm{p}=1.000)$ or seniority $(\mathrm{p}=0.140)($ Tab. 2$)$.

Table 2. Prevalence of anti-Coxiella antibodies in 126 Sicilian farmers: univariate analysis

\begin{tabular}{|c|c|c|c|c|c|c|}
\hline \multirow[t]{2}{*}{ Characteristics } & \multirow[t]{2}{*}{$\mathrm{N}^{\circ}$} & \multicolumn{2}{|c|}{$\begin{array}{l}\text { Presence of anti- } \\
\text { Coxiella antibodies }\end{array}$} & \multirow[t]{2}{*}{ OR } & \multirow[t]{2}{*}{$95 \% \mathrm{Cl}$} & \multirow[t]{2}{*}{$p$} \\
\hline & & $n$ & $\%$ & & & \\
\hline \multicolumn{7}{|l|}{ Province } \\
\hline Agrigento & 44 & 10 & 22.7 & 1.00 & & \multirow{3}{*}{0.044} \\
\hline Palermo & 62 & 11 & 17.7 & 0.73 & [0.28-1.93] & \\
\hline Trapani & 20 & 9 & 45.0 & 2.78 & [0.87-8.94] & \\
\hline \multicolumn{7}{|l|}{ Gender } \\
\hline Female & 42 & 9 & 21.4 & 1.00 & & \multirow[t]{2}{*}{0.657} \\
\hline Male & 84 & 21 & 25.0 & 1.22 & [0.47-3.38] & \\
\hline \multicolumn{7}{|l|}{ Age } \\
\hline$\leq 49.1$ & 63 & 15 & 23.8 & 1.00 & & \multirow[t]{2}{*}{1.000} \\
\hline$>49.1$ & 63 & 15 & 23.8 & 1.00 & {$[0.41-2.46]$} & \\
\hline \multicolumn{7}{|l|}{ Seniority } \\
\hline$\leq 22.5$ & 65 & 19 & 29.2 & 1.00 & & \multirow[t]{2}{*}{0.140} \\
\hline$>22.5$ & 61 & 11 & 18.0 & 0.53 & {$[0.21-1.33]$} & \\
\hline
\end{tabular}

As can be seen from the data shown on Tables 2 and 3, the mean age and seniority of workers coming from Palermo province found positive to both Phase I and II antibodies is significantly higher than in the rest of the sample. $60 \%$ (18 of $30 ; 95 \% \mathrm{CI}=[42.5-77.5])$ of seropositive samples were positive either for Phase I antigen, or for both Phase I and II antigens, representing cases of chronic infection (Tab.3).

Table 3. Provenance and number of seropositive subjects

\begin{tabular}{lcccc}
\hline $\begin{array}{l}\text { Provenance of } \\
\text { the sample }\end{array}$ & $\begin{array}{c}\text { Positive only } \\
\text { to phase I }\end{array}$ & $\begin{array}{c}\text { Positive only } \\
\text { to phase II }\end{array}$ & $\begin{array}{c}\text { Positive to } \\
\text { Phase I and II }\end{array}$ & $\begin{array}{c}\text { Total seropositive } \\
\text { samples }\end{array}$ \\
\hline Agrigento & 1 & 2 & 7 & 10 \\
\hline Trapani & 0 & 6 & 3 & 9 \\
\hline Palermo & 4 & 4 & 3 & 11 \\
\hline Total sample & 5 & 12 & 13 & 30 \\
\hline
\end{tabular}

Concerning the antibody titration, the range of seropositivity was between 1:16 and 1:128 (Tab. 4).

Table 4. Antibody titres found in positive subjects

\begin{tabular}{lccccc}
\hline $\begin{array}{l}\text { Provenance of } \\
\text { sample }\end{array}$ & $\begin{array}{c}\text { Positive } \\
1: 16\end{array}$ & $\begin{array}{c}\text { Positive } \\
1: 32\end{array}$ & $\begin{array}{c}\text { Positive } \\
1: 64\end{array}$ & $\begin{array}{c}\text { Positive } \\
1: 128\end{array}$ & $\begin{array}{c}\text { Total } \\
\text { seropositive } \\
\text { samples }\end{array}$ \\
\hline Agrigento & 1 & 1 & 4 & 4 & 10 \\
\hline Trapani & 4 & 2 & 2 & 1 & 9 \\
\hline Palermo & 5 & 5 & 1 & 0 & 11 \\
\hline Total sample & 10 & 8 & 7 & 5 & 30
\end{tabular}

To study the spread of the infection in cows and sheep raised in the same provinces, data collected from surveys carried out by Istituto Zooprofilattico Sperimentale of Sicily in various farms of the three provinces were analyzed. The number of farms and animals tested, with serology results, are shown in Table 5.

Table 5. Prevalence of infected animals in Sicilian tested farms: univariate analysis

\begin{tabular}{|c|c|c|c|c|c|c|c|}
\hline \multirow[t]{2}{*}{ Characteristics } & \multirow{2}{*}{$\begin{array}{l}\text { No. of } \\
\text { farms }\end{array}$} & \multirow{2}{*}{$\begin{array}{c}\text { No. of } \\
\text { tested } \\
\text { animals }\end{array}$} & \multicolumn{2}{|c|}{$\begin{array}{c}\text { Presence of } \\
\text { infected animals }\end{array}$} & \multirow[t]{2}{*}{ OR } & \multirow[t]{2}{*}{$95 \% \mathrm{Cl}$} & \multirow[t]{2}{*}{$p$} \\
\hline & & & $\mathrm{n}$ & $\%$ & & & \\
\hline Cows & 61 & 1511 & 46 & 3.04 & & & \multirow{4}{*}{$<0.001$} \\
\hline Agrigento & 12 & 151 & 22 & 14.6 & 1.00 & & \\
\hline Palermo & 46 & 1259 & 24 & 1.9 & 1.67 & {$[0.85-3.24]$} & \\
\hline Trapani & 3 & 101 & 0 & 0.0 & - & - & \\
\hline Sheep & 96 & 3391 & 548 & 16.16 & & & \multirow{4}{*}{0.167} \\
\hline Agrigento & 26 & 833 & 145 & 17.4 & 1.00 & & \\
\hline Palermo & 55 & 1882 & 284 & 15.1 & 1.19 & [0.95-1.48] & \\
\hline Trapani & 15 & 676 & 119 & 17.6 & 0.99 & {$[0.75-1.30]$} & \\
\hline
\end{tabular}

The number of infected bovines was not homogeneous along territory $(\mathrm{p}<0.001)$, with no positive lead found in Trapani. Alternatively, there was no significant difference in the number of infected sheep among Agrigento, Palermo and Trapani ( $\mathrm{p}=0.167)$. Applying Spearman's rank correlation, the percentage of seropositive humans was correlated with that observed for sheep $(r=1.00 ; p<0.001)$, but not for cows $(\mathrm{r}=-0.5 ; \mathrm{p}=0.667)$.

\section{DISCUSSION}

The obtained results, although based on a small sample, suggest that the disease is present in the territory of Western Sicily, infecting people found seropositive, even if not in direct contact with animals, nor clinically diagnosed for Q fever.

However, as outdoor workers, they were at greater risk of contracting the infection through infected aerosols: in fact, to be a farmer is recognized as a potential risk for biological exposure. In this regard, in a future study the authors intend to compare these findings with similar ones collected from individuals living in the same geographical areas, but performing indoor work tasks.

In the presented sample, seropositive status was never associated with a tick bite. Only one male subject reported a bite, but he had negative test results.

In this study, positive test results for Phase I, plus those positive for both phases (thus with chronic infection), were 18 out of 30 , equal to $60 \%$. In this regard, it would be appropriate to continue to monitor over time the remaining 12 seropositive subjects to assist their possible evolution to a chronic phase.

\section{CONCLUSIONS}

It is hard to estimate the true prevalence of the disease in human due to the lack of sufficient similar data for the exposed population in Italy [22]. Also, in other countries, such data are fragmentary and scientific studies are not 
always updated. In fact, $\mathrm{Q}$ fever is not a disease easily brought to the attention of doctors, in contrast to other zoonosis such as brucellosis, rickettsiosis or leishmaniasis.

Therefore, there is a tangible risk of underestimating the cases in the population, with missing or incorrect diagnosis in both acute events and chronic infections, along with resulting organ damages. The rarity of current disease reports could also be related to the several infections being completely asymptomatic or accompanied by atypical symptoms, hardly distinguishable from those caused by other diseases. For example, in this study all subjects showed no signs or symptoms of respiratory disease, and did not report any suggestive episode attributable to the time of infection. The study will be expanded in the near future, enrolling subjects with other work tasks not at direct risk of infection, to compare with those farmers in order to help assessing the related risk with this profession in the Sicilian region, where the disease had been described many decades ago [23, 24].

A study on the population at risk of exposure was also recently conducted on a group of veterinarians in the Netherlands where a persistent high level of IgG antibodies against Coxiella burnetii was found, presumably because of the continuous exposure to this pathogen during their work. The authors also assert the opportunity to monitor those subjects, as positivity can indicate a possible chronic $\mathrm{Q}$ fever in this occupational risk group [25].

In conclusion, it would be desirable and very helpful if there were greater collaborations between doctors and veterinarians, because the strategy to combat the spread of $\mathrm{Q}$ fever infection in humans can only be related to a better control of the pathogen in animals.

\section{Acknowledgements}

This work was supported by Grant No. IZS SI 05/12 RC from the Italian Health Ministry.

The authors thank Dr. Arnone Maria and Dr. Sciacca Carmela for their technical support.

\section{REFERENCES}

1. Borriello G, Iovane G, Galero G. La febbre Q negli animali domestici. Large Animal Rev. 2010; 16: 273-283.

2. SCIENTIFIC REPORT OF EFSA AND ECDC. The European Union Summary Report on Trends and Sources of Zoonoses, Zoonotic Agents and Food-borne Outbreaks in 2012. EFSA Journal 2014; 12(2): 3547.

3. Schimmer B, Schotten N, van Engelen E, Hautvast JL, Schneeberger PM, van Duijnhoven YT. Coxiella burnetii seroprevalence and risk for humans on dairy cattle farms, the Netherlands, 2010-2011. Emerg Infect Dis. 2014; 20(3): 417-25.

4. Khalili M, Mosavi M, Diali HG, Mirza HN. Serologic survey for Coxiella burnetii phase I II antibodies among slaughterhouse workers in Kerman, southeast of Iran. Asian Pac J Trop Biomed. 2014; 4(Suppl 1): S209-12.

5. O'Neill TJ, Sargeant JM, Poljak Z. The effectiveness of Coxiella burnetii vaccines in occupationally exposed populations: a systematic review and meta-analysis. Zoonoses Public Health. 2014; 61(2): 81-96.

6. Dorko E, Rimárová K, Pilipcinec E. Influence of the environment and occupational exposure on the occurrence of Q fever. Cent Eur J Public Health. 2012; 20(3): 208-14.
7. Whelan J, Schimmer B, Schneeberger P, Meekelenkamp J, Ijff A, van der Hoek W et al. Q fever among culling workers, the Netherlands, 2009-2010. Emerg Infect Dis. 2011; 17(9): 1719-23.

8. Walsh MG. Assessing Q fever in a representative sample from the United States population: identification of a potential occupational hazard. Epidemiol Infect. 2012; 140(1): 42-6.

9. Monno R, Fumarola L, Trerotoli P, Cavone D, Giannelli G, Rizzo C, et al. Seroprevalence of Q fever, brucellosis and leptospirosis in farmers and agricultural workers in Bari, Southern Italy. Ann Agric Environ Med. 2009; 16(2): 205-9.

10. Wilson LE, Couper S, Prempeh H, Young D, Pollock KG, Stewart WC et al. Investigation of a $\mathrm{Q}$ fever outbreak in a Scottish co-located slaughterhouse and cutting plant. Zoonoses Public Health. 2010; 57(7-8): 493-8.

11. Gidding HF, Wallace C, Lawrence GL, McIntyre PB. Australia's national Q fever vaccination program. Vaccine. 2009; 23;27(14): 2037-41.

12. Dorko E, Kalinova Z, Weissova T, Pilipcinec E. Seroprevalence of antibodies to Coxiella burnetii among employees of the Veterinary University in Kosice, eastern Slovakia. Ann Agric Environ Med. 2008; 15(1): 119-24.

13. de los Ríos-Martín R, Sanz-Moreno JC, Martín-Martínez F, TébarBetegón MA, Cortés-García M, Escudero-Nieto R. Q fever outbreak in an urban area following a school-farm visit. Med Clin (Barc). 2006; 126(15): 573-5.

14. Milazzo A, Featherstone KB, Hall RG. Q fever vaccine uptake in South Australian meat processors prior to the introduction of the National Q Fever Management Program. Commun Dis Intell Q Rep. 2005; 29(4): 400-6.

15. Deutz A, Fuchs K, Nowotny N, Auer H, Schuller W, Stünzner D et al. Sero-epidemiological studies of zoonotic infections in hunters-comparative analysis with veterinarians, farmers, and abattoir work. Wien Klin Wochenschr. 2003; 115 Suppl 3: 61-7.

16. Reid A, Malone J. Q fever in Ireland. A seroprevalence study of exposure to Coxiella burnettii among Department of Agriculture workers. Occup Med (Lond). 2004; 54(8): 544-7.

17. Abe T, Yamaki K, Hayakawa T, Fukuda H, Ito Y, Kume H et al. A seroepidemiological study of the risks of Q fever infection in Japanese veterinarians Eur J Epidemiol. 2001; 17(11): 1029-32.

18. Dahlgren FS, McQuiston JH, Massung RF, Anderson AD. Q Fever in the United States: summary of case reports from two national surveillance systems, 2000-2012. Am J Trop Med Hyg. 2015; 92(2): 247-55.

19. Gyuranecz M, Sulyok K, Balla E, Mag T, Balazs A, Simor Z et al. Q fever epidemic in Hungary, April to July 2013. Available on line at: Euro Surveill. 2014; 19(30).

20. Serrano-Pérez B, Almería S, Tutusaus J, Jado I, Anda P, Monleón E, et al. Coxiella burnetii total immunoglobulin G, phase I and phase II immunoglobulin $\mathrm{G}$ antibodies, and bacterial shedding in young dams in persistently infected dairy herds. J Vet Diagn Invest. 2015; pii: 1040638715571993. [Epub ahead of print].

21. R Guatteo, H Seegers, AF Taurel, A Joly, F Beaudeau. Prevalence of Coxiella burnetii infection in domestic ruminants: A critical review. Vet Microbiol. 2011; 149(1-2): 1-16.

22. Epicentro: Il portale dell'epidemiologia per la sanità pubblica, a cura del Centro Nazionale di Epidemiologia, Sorveglianza e Promozione della Salute. Available on line at: http://www.epicentro.iss.it/infettive/ default.asp.

23. Mirri A. Q fever in animals in Sicily and allergic diagnosis of Q fever in animals. Ann Sanita Pubblica. 1995; 11(3): 917-26.

24. Tringali G, Mansueto S. Epidemiology of Q fever in Italy and in other Mediterranean countries. Zentralbl Bakteriol Mikrobiol Hyg A. 1987; 267(1): 20-5.

25. Wielders CC, Boerman AW, Schimmer B, van den Brom R, Notermans DW, van der Hoek W et al. Persistent high IgG phase I antibody levels against Coxiella burnetii among veterinarians compared to patients previously diagnosed with acute $\mathrm{Q}$ fever after three years of follow-up. Available on line at: PLoS One. 2015; 10(1): e0116937. doi: 10.1371/ journal.pone.0116937. eCollection 2015. 